\title{
Assessment of Neutrophil to Lymphocyte and Platelet to Lymphocyte Ratios in Patients with Temporal Lobe Epilepsy
}

\section{Temporal Lob Epilepsili Hastalarda Nötrofil/Lenfosit ve Trombosit/Lenfosit Oranlarının Değerlendirilmesi}

\author{
(1) Oğuz BARAN, ${ }^{1}$ (1) Taha Şükrü KORKMAZ, ${ }^{2}$ 이 Rahsan KEMERDERE, ${ }^{2}$ \\ (1) Eren Fatma AKÇIL, ${ }^{3}$ ㄴ) Seher Naz YENI, ${ }^{4}$ @ Mustafa UZAN, ${ }^{2}$ \\ (1) Taner TANRIVERDi ${ }^{2}$
}

'Department of Neurosurgery, Haseki Training and Research Hospital, İstanbul ${ }^{2}$ Department of Neurosurgery İstanbul University-Cerrahpaşa, Cerrahpaşa Faculty of Medicine, İstanbul ${ }^{3}$ Department of Anesthesiology and Reanimation, İstanbul University-Cerrahpaşa, Cerrahpaşa Faculty of Medicine, İstanbul ${ }^{4}$ Department of Neurology, İstanbul University-Cerrahpaşa, Cerrahpaşa Faculty of Medicine, İstanbul

\section{Summary}

Objectives: This retrospective study aims to evaluate preoperative levels of neutrophil to lymphocyte (NLR) and platelet to lymphocyte ratios (PLR) in patients with temporal lobe epilepsy and to compare with controls.

Methods: Patients and control groups consisted of 36 and 35 subjects, respectively, and routine complete blood count was obtained for NLR and PLR analysis.

Results: The two ratios were higher in patients, but differences were not significant ( $p>0.05)$. Disease severity, such as high seizure frequency, duration of seizure, and presence of the history of febrile seizure, was not significantly correlated either with NLR or PLR. Findings did not provide evidence of usefulness for discrimination between temporal lobe epilepsy and controls.

Conclusion: Further prospective studies, including a larger sample size, should be conductedto have more valuable results for interpretation. Keywords: Epilepsy; inflammation; neutrophil to lymphocyte ratio; platelet to lymphocyte ratio; temporal lobe epilepsy.

\section{Özet}

Amaç: Bu geriye dönük çalışmanın amacı, temporal lob epilepsili hastalarda preoperatif nötrofil/lenfosit ve trombosit/lenfosit oranını değerlendirmektir.

Gereç ve Yöntem: Nötrofil/lenfosit ve trombosit/lenfosit oranı analizi için temporal lob epilepsili 36 kişi ile kontrol grubunun hemogramları geriye dönük olarak değerlendirildi.

Bulgular: Her iki oran da hasta grubunda daha yüksek saptandı ancak anlamlı farklılık saptanmadı ( $p>0.05)$. Nöbet sıklığı, nöbet süresi ve febril konvülsiyon ile nötrofil/lenfosit ve trombosit/lenfosit oranı arasında anlamlı ilişki bulunamamıştır. Sonuçlar, temporal lob epilepsili hastalarda nötrofil/lenfosit ve trombosit/lenfosit oranlarının kullanımına ilişkin kanıt sağlamamıştır.

Sonuç: Genellenebilir sonuçlara ulaşmak için daha geniş ölçekli ileriye yönelik çalışmalara ihtiyaç vardır.

Anahtar sözcükler: Epilepsi; inflamasyon; nötrofil/lenfosit oranı; trombosit/lenfosit oranı; temporal lob.

(C) 2020 Türk Epilepsi ile Savaş Derneği

(C) 2020 Turkish Epilepsy Society
Submitted (Geliş): 23.03.2019

Accepted (Kabul) : 02.05.2019

Correspondence (illetişim): Oğuz BARAN, M.D.

e-mail (e-posta): oguzbaran@gmail.com 


\section{Introduction}

Temporal lobe epilepsy (TLE) with hippocampal sclerosis (HS) is the most common form of localization-related epilepsy, and the most effective treatment currently is surgery. ${ }^{[1]}$ The exact pathophysiology behind TLE-HS is not very well-known. Thus, medical treatment can control seizures for a limited period of time but cannot prevent the progression of the disease. Substantial evidence from in vivo and in vitro studies have shown that TLE-HS is a progressive disease with increasing seizure frequency even after surgery and uncontrolled progressive inflammation could be a factor. ${ }^{[2,3]} \mathrm{A}$ majority of patients with TLE-HS have a history of a risk factor, such as febrile seizures or infection in their early life, and these risk factors, may cause HS. Studies on the surgically-resected epileptic tissues showed all hallmarks of inflammation or inflammatory cells, including leukocytes. ${ }^{[4]}$ Furthermore, animal models of epilepsy highlight the possibility of inflammation as a contributing factor for the occurrence and/or progression of epilepsy, especially TLE-HS. ${ }^{[5]}$ Recent literature regarding control of seizure in patients with epilepsy suggests that giving effective anti-inflammatory drug together with traditional anti-epileptic drugs (AED) may be more effective in controlling seizure and preventing disease progression than giving AED alone. ${ }^{[6,7]}$

Recently, there are many clinical studies demonstrating that neutrophil to lymphocyte ratio (NLR) and platelet to lymphocyte ratio (PLR) can be used as an inflammatory marker predicting the disease progression. Thus, many studies have shown that higher NLR, as well as PLR, are positively correlated with disease progression in inflammatory brain diseases ${ }^{[8]}$ and indicate poor prognosis or shorter survival in many cancers, including brain gliomas and brain metastasis. ${ }^{[9,10]}$ Studies stated that these peripheral inflammatory parameters can be obtained from routine complete blood count $(C B C)$ tests, which are very cheap and easily performed.

The authors believe that TLE-HS is a chronic inflammatory brain disorder, and prolonged inflammation leads to increased neutrophil and decreased lymphocyte counts with thrombocytosis. Thus, the present study aims to retrospectively evaluate how NLR and PLR levels in patients with TLE-HS change compared to controls and is there any association between these ratios and seizure frequency and/or duration of the seizure.

\section{Materials and Methods}

\section{Patients}

For this retrospective analysis of $\mathrm{CBC}$, a total of 36 consecutive patients who underwent surgery for TLE were included in this study. All patients were discussed extensively in our local epilepsy meetings and completed pre-operative workup according to epilepsy protocol, including head magnetic resonance imaging (MRI), positron emission tomography (PET), and neuropsychological tests. If needed, functional MRI for speech and/or memory dominance and depth electrode insertion for bilateral TLE were applied. As expected, all patients were on AED before surgery. As in all epilepsy centers, the extent of temporal lobe resections including mesial structures, such as hippocampal-parahippocampal complex, was decided depending on results from pre-operative work-up not to cause severe memory and/or speech defects. Clinical characteristics and CBC tests were obtained from the patients' files. Our patient group had no signs of infection and other organ system diseases other than TLE.

\section{Controls}

Control group in this study composed of 35 subjects who admitted to our clinic and obtained CBC tests for some other reasons, such as headache. All subjects showed no abnormality in their head MRI and no other organ system illness.

\section{Laboratory analysis}

Leukocyte, lymphocyte, platelet, and neutrophil counts $\left(x 10^{3} \mathrm{~mm}^{3}\right)$ were obtained from peripheral venous blood samples. NLR and PLR were calculated by dividing the absolute neutrophil and platelet counts by the absolute lymphocyte count, respectively.

\section{Statistical analysis}

We used a commercially available statistical software package (SPSS version 15.0 Inc., Chicago, Illinois, USA) for all statistical analyses. The mean \pm standard deviation was calculated for each parameter. The independent samples t-test and chisquare test were used for appropriate comparisons. Correlation analysis was evaluated using Pearson correlation tests. Differences were considered statistically significant if $\mathrm{p}<0.05$.

\section{Results}

The patient group included 20 males and 16 females with a mean age of 33.6 \pm 9.6 years (range: $18-59$ years). Mean seizure onset and mean seizure duration were found to 
be $11 \pm 8.9$ years (range: 6 months -35 years) and $18.7 \pm 9.2$ years (range: $1-40$ years). A total of $18(50 \%)$ patients had a history of febrile seizure and in seven (19\%) patients, hypometabolism on PET was extensive, including temporal lobe plus other areas (temporal-plus).

Control group had 19 males and 16 females with a mean age of 32 \pm 10 years (range: 10-51 years). Comparisons between the two groups regarding gender ( $x^{2}$ test; $p=0.74$ ) and mean age $(p=0.51)$ showed no difference.

Mean levels of leukocyte, lymphocyte, platelet, and neutrophil counts were higher in controls than patients and the differences were significant except neutrophil counts. Expectedly, NLR and PLR were higher in patients than controls, but differences were not significant (Table 1).

Since febrile seizures are one of the contributors to inflammation in the pathogenesis of TLE, the authors wonder how this contributor can change the peripheral inflammatory markers. Mean levels of leukocyte, neutrophil, and NLR were higher in the in patients who had a history of febrile seizures compared to the patients without a history of febrile seizures. However, all parameters evaluated here did not show any significant differences between the two groups ( $p>0.05$ ). Expectedly, NLR and PLR disclosed higher mean levels in those patients with and without a history of febrile seizures compared to controls, but differences were not significant ( $p>0.05)$ (Table 2 ).

In this study, the effects of extending hypometabolism on PET on peripheral blood parameters was also evaluated

Table 1. Summary of statistical analysis related to laboratory findings between patients and controls

\begin{tabular}{lcccc}
\hline Parameters & $\begin{array}{c}\text { Patients } \\
(\mathrm{n}=36)\end{array}$ & & $\begin{array}{c}\text { Controls } \\
(\mathrm{n}=35)\end{array}$ & $\mathrm{p}$ \\
\cline { 2 - 2 } \cline { 5 - 5 } & Mean $\pm \mathrm{SD}$ & & Mean $\pm \mathrm{SD}$ & \\
\hline Leukocyte & $6.22 \pm 2.37$ & & $7.29 \pm 1.14$ & 0.02 \\
Lymphocyte & $1.77 \pm 0.52$ & & $2.39 \pm 0.54$ & 0.00001 \\
Platelet & $212 \pm 48.5$ & & $271.5 \pm 57.6$ & 0.00001 \\
Neutrophil & $3.68 \pm 2.49$ & & $4.20 \pm 0.81$ & 0.24 \\
NLR & $2.66 \pm 3.70$ & & $1.83 \pm 0.49$ & 0.19 \\
PLR & $132.8 \pm 60.2$ & & $118.5 \pm 34.2$ & 0.22 \\
\hline
\end{tabular}

NLR: Neutrophil to lymphocyte ratio; PLR: Platelet to lymphocyte ratio; SD: Standard deviation.
(Table 3). Only lymphocyte count was higher in "temporal-plus" group compared to "temporal lobe only" involvement and the difference was not significant $(p=0.59)$. Neutrophil count significantly increased in "temporal lobe only" group compared with "temporal-plus" group $(p=0.02)$. Other parameters, although higher in "temporal lobe only" group, did not show a significant difference $(p>0.05)$. All parameters except NLR and PLR showed significantly higher levels in controls than the "temporalplus" group $(p<0.05)$. However, comparing controls and "temporal lobe only" group showed significant higher levels in controls regarding lymphocyte $(p=0.00001)$ and platelet counts $(p=0.00001)$.

Table 2. Mean and standard deviations of laboratory findings related to those with presence and with the absence of the history of febrile seizures and controls

\begin{tabular}{|c|c|c|c|}
\hline \multirow[t]{2}{*}{ Parameters } & $\begin{array}{c}\mathrm{FS}+ \\
(n=18)\end{array}$ & $\begin{array}{c}\text { FS - } \\
(n=18)\end{array}$ & $\begin{array}{l}\text { Controls } \\
(n=35)\end{array}$ \\
\hline & Mean $\pm S D$ & Mean $\pm S D$ & Mean $\pm S D$ \\
\hline Leukocyte & $6.51 \pm 3.0$ & $5.94 \pm 1.4$ & $7.29 \pm 1.14$ \\
\hline Lymphocyte & $1.78 \pm 0.5$ & $1.76 \pm 0.4$ & $2.39 \pm 0.5$ \\
\hline Platelet & $204.7 \pm 42.0$ & $219.2 \pm 54.5$ & $271.5 \pm 57.6$ \\
\hline Neutrophil & $3.98 \pm 3.1$ & $3.39 \pm 1.7$ & $4.20 \pm 0.8$ \\
\hline NLR & $3.08 \pm 4.9$ & $2.23 \pm 1.7$ & $1.83 \pm 0.4$ \\
\hline PLR & $132.4 \pm 71.8$ & $133.2 \pm 47.9$ & $118.5 \pm 34.2$ \\
\hline
\end{tabular}

FS +: Presence of history of febrile seizures; FS -: Absence of history of febrile seizures; NLR: Neutrophil to lymphocyte ratio; PLR: Platelet to lymphocyte ratio; SD: Standard deviation.

Table 3. Mean and standard deviations of laboratory findings related to the extent of hypometabolism on positron emission tomography in patients and controls

\begin{tabular}{lccccc}
\hline Parameters & $\begin{array}{c}\text { TL-plus } \\
(\mathrm{n}=7)\end{array}$ & & $\begin{array}{c}\text { TL only } \\
(\mathrm{n}=29)\end{array}$ & & $\begin{array}{c}\text { Controls } \\
(\mathrm{n}=35)\end{array}$ \\
\cline { 2 - 2 } \cline { 5 - 6 } & Mean \pm SD & & Mean $\pm S D$ & & Mean $\pm S D$ \\
\hline Leukocyte & $5.19 \pm 0.8$ & & $6.47 \pm 2.5$ & & $7.29 \pm 1.14$ \\
Lymphocyte & $1.87 \pm 0.4$ & & $1.75 \pm 0.5$ & & $2.39 \pm 0.5$ \\
Platelet & $210.4 \pm 70.3$ & & $212.3 \pm 43.4$ & & $271.5 \pm 57.6$ \\
Neutrophil & $2.67 \pm 0.3$ & & $3.93 \pm 2.7$ & & $4.20 \pm 0.8$ \\
NLR & $1.47 \pm 0.2$ & & $2.95 \pm 4$ & & $1.83 \pm 0.4$ \\
PLR & $122 \pm 61.8$ & & $135.4 \pm 60.6$ & & $118.5 \pm 34.2$ \\
\hline
\end{tabular}

NLR: Neutrophil to lymphocyte ratio; PLR: Platelet to lymphocyte ratio; TL: Temporal lobe; TL-plus: Temporal lobe plus (hypometabolism involving the temporal lobe plus other lobes); SD: Standard deviation. 
Pearson correlation analysis showed that NLR correlated positively with seizure duration and negatively with the presence of the history of the febrile seizure, seizure frequency and extent of hypometabolism on PET. However, none of the correlations reached a significant level ( $p>0.05$ ). A positive correlation was also found between PLR and presence of history of febrile seizure and seizure duration. However, seizure frequency and extent of hypometabolism on PET negatively correlated with PLR. Again, none of them reached significant level $(p>0.05)$. A significant positive correlation was found between NLR and PLR $(p=0.00001)$.

Receiver operating characteristics (ROC) curve analysis for discrimination between patients and controls (Fig. 1) showed the area under the curve (AUC) for NLR was 0.43 with insignificant $p$-value $(p=0.33)$. The cut-off point was 2.04 and the test specificity $(74 \%)$ and sensitivity $(22 \%)$ were low. The AUC was found to be 0.55 with a $p$-value of greater than 0.05 ( $p=0.33$ ) for PLR. The cut-off point was 138.16, and specificity and sensitivity were 71 and $41 \%$, respectively.

\section{Discussion}

To our knowledge, this is the first study to assess how NLR and PLR change in patients with TLE and to show the possibility of correlation(s) between these two inflammatory parameters and disease activity. Different from previous publications in which either NLR or PLR showed significant

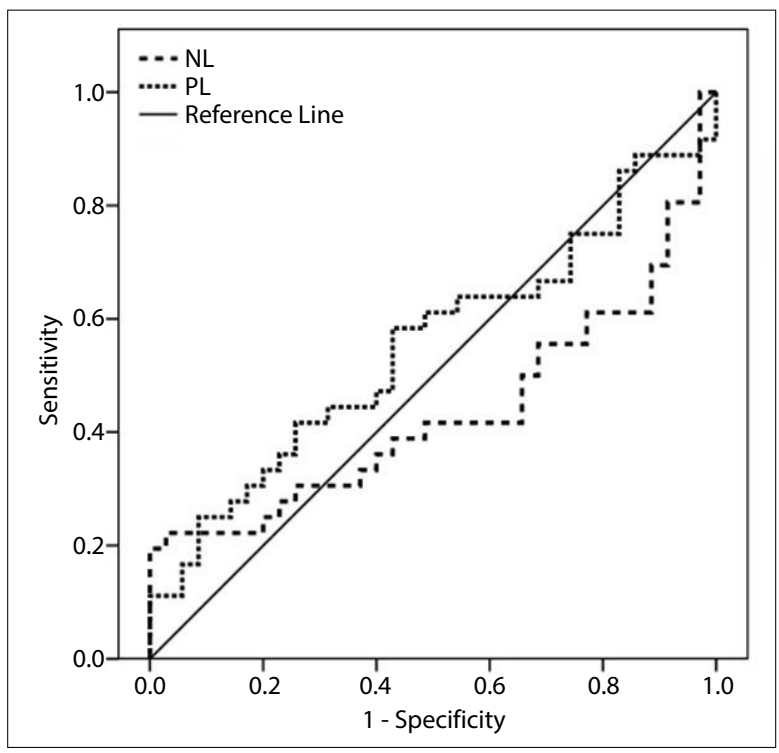

Fig. 1. Receiver operating curve analysis of neutrophil to lymphocyte and platelet to lymphocyte ratios for discrimination between patients and controls. higher levels compared to controls or correlated with disease activities in inflammatory brain disorders ${ }^{[8]}$ or some brain tumors, such as gliomas and brain metastasis. ${ }^{[9,10]}$ As expected, NLR and PLR are higher in patients compared to controls but the difference did not reach a significant level. We expected significantly higher levels of NLR and PLR in the patients who had history of febrile seizures, longer duration of epilepsy, higher seizure frequency and larger extension of hypometabolism on PET study compared to the patients who did not have but our results do not provide evidence for the association between NLR/PLR and disease activity. Furthermore, we found a trend to have a positive correlation between seizure duration, presence of the history of febrile seizures and NLR/PLR, but correlations were not significant. More importantly, these tests are not sensitive and/or specific for discrimination of TLE and controls.

Elevated NLR and PLR have been shown to be a useful predictor for disease activity and survival in patients with various inflammatory diseases and cancers, but evaluation of these two parameters has not been studied in TLE. There have been only a few reports in which NLR was studied for the differentiation of simple (SFS) and complex febrile seizures (CFS) in only two reports ${ }^{[11,12]}$ and in one, change in serum levels of NLR was assessed in children with convulsive status epilepticus (CSE). ${ }^{[13]}$ Goksugur et al. ${ }^{\left[{ }^{[1]}\right.}$ found that NLR is significantly higher in patients with CFS than SFS and they concluded that this ratio can differentiate these two seizure types because inflammatory responses are more powerful in CFS than SFS. Similarly, Yigit et al. ${ }^{[12]}$ support the notion that NLR is significantly higher in CFS compared to SFS, but different from the aforementioned study, they concluded that levels of NLR did not produce a clear-cut distinction. Another study by Özdemir et al. ${ }^{[13]}$ showed that NLR is significantly higher in children with CSE and concluded that neutrophil-mediated inflammation may be an important etiological factor in CSE.

We cannot compare our results with the results from the aforementioned three studies because of different age groups and epilepsy types included in these studies. Our group included patients with TLE and our results showed that these two ratios could not be used for discrimination between TLE and controls, and the levels do not correlate with disease activity. Depending on the current results, we can speculate that inflammation in the brain in TLE does not affect on the relative levels of circulation inflammatory mol- 
ecules. However, results related to epilepsy, including ours, should be evaluated cautiously because this study included fewer number of patients.

\section{Limitations}

There are two major limitations to this study. One limitation is its retrospective nature and the other limitation is that the present study has a relatively small sample size. More accurate data may be drawn in future prospective studies including a larger number of patients with TLE.

\section{Conclusion}

Inflammatory parameters, NLR and PLR, are not significantly increased in patients with temporal lobe epilepsy and cannot be used as a marker of disease severity, such as seizure frequency, duration of seizure, presence of a history of febrile seizures and extension of hypometabolism.

\section{Ethics Committee Approval}

Resrospective study.

\section{Peer-review}

Externally peer-reviewed.

\section{Conflict of interest}

The authors declare that they have no conflict of interest.

\section{Authorship Contributions}

Concept: R.K., T.T.; Design: T.T.; Supervision: S.N.Y., M.U.; Materials: T.Ş.K.; Data collection \&/or processing: O.B.; Analysis and/or interpretation: O.B., E.F.A.; Literature search: T.Ş.K.; Writing: O.B., T.T.; Critical review: S.N.Y., M.U.

\section{References}

1. Olivier A, Boling WW, Tanriverdi T. Techniques in epilepsy surgery: The MNI approach. UK: Cambridge University Press; 2012.

2. Pitkänen A, Sutula TP. Is epilepsy a progressive disorder? Prospects for new therapeutic approaches in temporal-lobe epilepsy. Lancet Neurol 2002;1(3):173-81. [CrossRef]
3. Yang T, Zhou D, Stefan H. Why mesial temporal lobe epilepsy with hippocampal sclerosis is progressive: uncontrolled inflammation drives disease progression? J Neurol Sci 2010;296(12):1-6. [CrossRef]

4. Vezzani A, French J, Bartfai T, Baram TZ. The role of inflammation in epilepsy. Nat Rev Neurol 2011;7(1):31-40. [CrossRef]

5. Silverberg J, Ginsburg D, Orman R, Amassian V, Durkin HG, Stewart M. Lymphocyte infiltration of neocortex and hippocampus after a single brief seizure in mice. Brain Behav Immun 2010;24(2):263-72. [CrossRef]

6. Ahmedov ML, Kemerdere R, Baran O, Inal BB, Gumus A, Coskun $C$, et al. Tissue Expressions of Soluble Human Epoxide Hydrolase-2 Enzyme in Patients with Temporal Lobe Epilepsy. World Neurosurg 2017;106:46-50. [CrossRef]

7. Walker L, Sills GJ. Inflammation and epilepsy: the foundations for a new therapeutic approach in epilepsy? Epilepsy Curr 2012;12(1):8-12. [CrossRef]

8. Mallucci G, Peruzzotti-Jametti L, Bernstock JD, Pluchino S. The role of immune cells, glia and neurons in white and gray matter pathology in multiple sclerosis. Prog Neurobiol 2015 Apr;127128:1-22. [CrossRef]

9. Auezova R, Ryskeldiev N, Doskaliyev A, Kuanyshev Y, Zhetpisbaev $\mathrm{B}$, Aldiyarova $\mathrm{N}$, et al. Association of preoperative levels of selected blood inflammatory markers with prognosis in gliomas. Onco Targets Ther 2016;9:6111-7. [CrossRef]

10. Mitsuya K, Nakasu Y, Kurakane T, Hayashi N, Harada H, Nozaki K. Elevated preoperative neutrophil-to-lymphocyte ratio as a predictor of worse survival after resection in patients with brain metastasis. J Neurosurg 2017;127(2):433-7. [CrossRef]

11. Goksugur SB, Kabakus N, Bekdas M, Demircioglu F. Neutrophilto-lymphocyte ratio and red blood cell distribution width is a practical predictor for differentiation of febrile seizure types. Eur Rev Med Pharmacol Sci 2014;18(22):3380-5.

12. Yigit Y, Yilmaz S, Akdogan A, Halhalli HC, Ozbek AE, Gencer EG. The role of neutrophil-lymphocyte ratio and red blood cell distribution width in the classification of febrile seizures. Eur Rev Med Pharmacol Sci 2017;21:554-9.

13. Özdemir HH, Akil E, Acar A, Tamam Y, Varol S, Cevik MU, et al. Changes in serum albumin levels and neutrophil-lymphocyte ratio in patients with convulsive status epilepticus. Int J Neurosci 2017;127(5):417-20. [CrossRef] 